\section{New Orleans was prepared but it was overwhelmed}

SIR - Your Editorial "The gathering storm" (Nature 441, 549; 2006) states: "the voters of New Orleans, many still scattered across the country, managed last month to re-elect Mayor Ray Nagin, the individual most closely associated with the city's woeful failure to prepare itself for the storm." As an affected resident of the region, I find this statement both untrue and an obstacle to better preparedness for future disasters that will impact on this country.

Although your statement may resemble truth for those who watched the disaster on television, for those who lived through it, Mayor Nagin is associated with a city and region that was as prepared as much as reasonably possible. If not for his leadership, many more would have died and long-term recovery would be much further behind.

A Times-Picayune article of 27 August 2005, two days before landfall, notes that Nagin "would stick with the state's evacuation plan" developed by state and local officials after Hurricane Ivan. The successful implementation of this plan facilitated the evacuation of more than a million people during a 48-hour period, an accomplishment considered impossible by all the experts. A US Army Corps of Engineers study, for example, concluded that 72 hours would be required to evacuate New Orleans.

Additionally, there has been much discussion of the difficulties faced by 100,000 residents without access to private transport. However, the available data indicate that approximately $65 \%$ of people without vehicles left the city before the onset of hazardous conditions.

For those who faced serious difficulties in leaving the city, local officials provided the Superdome as a shelter of last resort. The use of the Superdome has been the subject of much criticism. However, of the 72,000 people who remained in the city after the evacuation, 26,000 were protected from Katrina's winds and floodwaters because of this shelter. Hundreds of these people would have died if the city had not provided this shelter of last resort. Contrary to the common perception, the people in the Superdome were provided with food, water and security. The nightmare only began when the Federal Emergency Management Agency was three days late in sending the buses for post-storm evacuation.

Many people in the United States believe that the lesson to be learned from Hurricane Katrina is that a catastrophe happened because the state and local officials were not prepared. However, the evidence on the ground indicates an unprecedented level of preparedness at the state and local level. Yet a catastrophe still occurred. In my opinion, the lesson to be learned is that, even in a context of extensive preparedness, state and local officials will be overwhelmed by natural hazards of extraordinary magnitude, and that the country as a whole needs to be prepared for this outcome. As your Editorial points out, we are likely to be entering an era of more frequent and more intense hurricane and flood disasters.

\section{Ezra Boyd}

Center for the Study of the Public Health Impacts of Hurricanes, Suite 3221 CEBA Building, Louisiana State University, Baton Rouge, Louisiana 70803, USA

\section{Cells have long experience of dealing with UVC light}

SIR - In his News and Views article "Device physics: A bug-beating diode" (Nature 441, 299; 2006) describing the development of UVC-emitting diodes that promise to have major practical applications, Asif Khan states: "Earth's ozone layer completely blocks solar light of very low ultraviolet wavelengths. Biological organisms on Earth have therefore never developed a tolerance for this 'UVC' radiation, and artificially generated UVC light has become a useful tool in the treatment and destruction of bacteria, yeast, viruses and fungi."

This statement is in error on many counts. Biological organisms existed on Earth before an oxygen atmosphere, approximately 2 billion years ago, and therefore before the protection afforded by the ozone layer. During this period, cells had ample time to experience UVC (260 nm wavelength). Evolutionary pressures led to the development of multiple repair and tolerance systems targeting UVC-induced cellular damage that are now found in all three biological kingdoms. (Early evidence for repair in bacteria is shown, for example, in R. F. Hill Biochim. Biophys. Acta 30, 636-637; 1958.) Loss of a UVC repair system in humans results in the UV-sensitive disease xeroderma pigmentosum, first described in 1968 (J. E. Cleaver Nature 218, 652; 1968).

Even after the appearance of the ozone layer, evolutionary pressure continued because of the similarity of the photochemistry of DNA exposed to UVC and to UVB (280-320 nm). Exposure to either wavelength results in similar photoproducts: covalent adducts between adjacent pyrimidines on the DNA strands (known as cyclobutane pyrimidine dimers and [6-4]-photoproducts). The difference between DNA damage at these wavelengths is mainly different relative proportions of photoproducts and different proportions of cytosine- and thymine-containing photoproducts.
Another misapprehension is that cells need exposure to a particular agent to develop resistance mechanisms to that agent. This fails to appreciate the versatility of most biological repair systems. DNA damage can involve a wide range of altered chemical structures, but is constrained by the structure of DNA itself. Repair systems consequently target specific structural alterations as well as general classes of lesions. The nucleotide excision repair system that repairs UVC damage excises a wide variety of DNA damage, even adducts formed by an agent such as cisplatin, which was unknown to biology before its human invention in recent years.

There is therefore ample evidence that repair and tolerance systems towards UVC have existed for long evolutionary periods and have great versatility. UVC light has become a useful tool in the treatment and destruction of bacteria, yeast, viruses and fungi because it is technically easy to generate high dose rates at a wavelength (254 nm) close to the absorption maximum of DNA with low-pressure mercury sources, not because cells lack tolerance or repair mechanisms.

\section{James E. Cleaver}

Department of Dermatology and

Pharmaceutical Chemistry,

Auerback Melanoma Laboratory, UCSF Cancer Center, University of California San Francisco, San Francisco, California 94143-0808, USA

\section{Same colour, many different countries}

SIR - Michael Chen, in Correspondence (Nature 442, 132; 2006), raised a question about the colours used in a map with the News Feature "Forward planning" (Nature 440, 987-989; 2006). He was concerned that showing both the People's Republic of China and Taiwan as yellow would make people think that they comprised one country. However, all the countries shown as having proposed repositories for nuclear waste are coloured yellow, including Sweden, Finland, the United Kingdom and France. This certainly does not mean that these pairs of neighbouring countries have been united into one.

According to the World Nuclear Association (www.world-nuclear.org), Taiwan has nuclear power reactors in operation, and therefore it should not be excluded from the issue discussed in the News Feature. I can see nothing wrong with the colours used in the map. Being simple and focused, it fulfilled its purpose.

\section{Zhen-Ling Sun}

Department of Animal and Plant Sciences, Alfred Denny Building, University of Sheffield, Western Bank, Sheffield S10 2TN, UK 